\title{
Editorial
}

\section{Editorial: Words Hurt - Avoiding Dehumanizing Language in Orthopaedic Research and Practice}

\author{
Seth S. Leopold MD, Lee Beadling BS, \\ Mark C. Gebhardt MD, Terence J. Gioe MD, \\ Benjamin K. Potter MD, Clare M. Rimnac PhD, \\ Montri D. Wongworawat MD
}

$\mathrm{T}$ he words we use in scientific reporting and patient care matter. Poorly chosen and carelessly used words - dehumanizing language - can hurt. These words can hurt patients' feelings, they can harm

The authors certify that they, or any members of their immediate families, have no commercial associations (eg, consultancies, stock ownership, equity interest, patent/ licensing arrangements, etc) that might pose a conflict of interest in connection with the submitted article.

All ICMJE Conflict of Interest Forms for authors and Clinical Orthopaedics and Related Research ${ }^{\mathbb{R}}$ editors and board members are on file with the publication and can be viewed on request.

The opinions expressed are those of the writers, and do not reflect the opinion or policy of $C O R R^{\circledR}$ or the Association of Bone and Joint Surgeons ${ }^{\circledR}$.

S. S. Leopold MD $(\bowtie) \cdot$ L. Beadling BS

Clinical Orthopaedics and Related

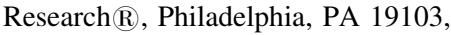

USA

e-mail: sleopold@clinOrthop.org

M. C. Gebhardt MD

Department of Orthopaedic Surgery, Beth Israel Deaconess Medical Center, Boston, MA, USA

\section{T. J. Gioe MD}

Department of Orthopaedic Surgery,

University of Minnesota Medical

School, Minneapolis, MN, USA our relationships with our patients, and they can change the way we perceive those whom we care for or write about in ways that diminish our ability to work effectively on their behalf.

Who would use such language? In fact, many of us do at times, often without even realizing it. Patients are people, they are not "cases," though spoken language and research reports often suggest they are. With surprising frequency, we receive papers with sentences like, "Patients that present for treatment of ..." when plainly patients, as people, should be referred to with the relative pronoun "who." These can be careless mistakes. However, in a recent paper, we saw that same construction followed by, “... and the surgeons who treat them ..."

\section{B. K. Potter MD}

Department of Orthopaedics and Rehabilitation, Walter Reed National Military Medical Center, Bethesda, MD, USA

C. M. Rimnac PhD

Case Western Reserve University

School of Engineering, Cleveland, OH, USA

M. D. Wongworawat MD

Department of Orthopaedic Surgery, Loma Linda University Medical Center, Loma Linda, CA, USA
Some of us might refer to a patient as a "diabetic," but we would not consider calling someone a "schizophrenic" or an "epileptic." The reason we prefer people-first usages like "patient with diabetes" or "individual with schizophrenia" is that this kind of language makes it more clear that our patients are much more than the sum of their particular diagnoses. Sometimes language one may perceive as being politically correct is simply correct.

Along that same line, the way we characterize control groups in research studies can change our perceptions about the patients with the disease or condition being studied. Describing a control group as consisting of "normal" or "able-bodied" individuals conveys specific implications about the treatment groups that seldom are correct, and in some instances, can be both misleading and insulting. Many diagnoses, from obesity to limb loss to arthritis are attached to patients who feel they are both healthy and ablebodied and who, in most important respects, are able-bodied. Saying or writing otherwise influences both patients' self-perceptions and our preconceived ideas about these individuals in ways that do not improve our ability to help care for them. 
Sometimes, people-first language does not fit the bill. Recently, in the course of processing papers for a symposium on care of patients with limb loss, it became evident that nearly all the papers referred to patients as "amputees." A case of mass insensitivity? Quite the opposite. Some groups of patients with particular diagnoses choose to self-define through the language they use. Patients who have had amputations appear to be one such group. Even the names of some leading advocacy groups - the Amputee Coalition (formerly the Amputee Coalition of America) (www.amputee-coalition.org) as well as the Paralyzed Veterans of America (www.pva.org) - make this quite plain. Those who have cared for patients with these diagnoses know that in some settings, the descriptive language some patients use can get quite colorful. Both in medicine and outside it, groups of individuals who have been marginalized commonly will reclaim language and use it in ways that would not be acceptable outside the group. Language is power.

Making matters more complicated, we find that even experts can disagree. Springboard Consulting, a marketing firm that specializes on reaching communities of people with disabilities, has numerous references to "the disabled" [7] and "the disability community" [6] on its website. While the New York Times has some general guidelines [1] similar to the approach we are advocating here, the Times does not always get it right, referring to "the disabled" as a population both in a headline and the related text on its editorial page [3]. Still further along the spectrum, the state of Arizona has outlawed use of terms like "disabled" and "handicapped" in its state laws [5], in favor of people-first language, although the fact that most other states have not done this suggests that this issue remains to some degree unsettled, and perhaps something of a moving target, even among those who care deeply about it.

Physicians and surgeons are generally good people. Why do we use dehumanizing language in the office and in scientific writing to the degree we do? Others have offered thoughtful speculation on the topic [2, 4], but we see few certainties here. We do not know whether physicians use this kind of language to generate emotional distance as a coping mechanism against the failures we inevitably encounter and sometimes cause. Perhaps this kind of language is no more than a time-saving shorthand used by busy people. If the former, we believe there must be better ways to provide for our own emotional needs than to dehumanize those whom we care for. If the latter, we believe pausing to speak or write an extra few syllables to be well worth the effort expended.

Although thoughtful individuals and groups differ on how best to handle this, and we imagine that patients may differ in terms of how they would like to be called (and indeed, some may not care), we nonetheless will make every reasonable attempt to choose language that reflects that each patient - each person has many traits other than a particular diagnosis. To that end, we will use terms like "patients with diabetes" instead of "diabetics" unless it is unreasonably cumbersome to do so, or unless we know that patients in a particular group generally have other preferences. We will seek to choose value-neutral terminology for control groups so as not to project inappropriate inferences about the patients in the treatment groups. We will not refer to human beings as "cases."

We will try to carry this value set with us into our offices, operating rooms, teaching sessions, and laboratories.

Acknowledgments The authors would like to thank Ms. Loreen Loonie, of Independence Care System, for providing an interview and background information on this important topic. We also are grateful to Matthew B. Dobbs MD, Paul A. Lotke MD, and Paul A. Manner MD for participating in the conversations that guided this essay.

\section{References}

1. Corbett PB. Language and disabilities. Available at: http://afterdeadline. blogs.nytimes.com/2009/01/06/language-and-disabilities/. Accessed June 17, 2014.

2. Donnelly WJ. Lingua medica - The language of medical case histories. Ann Int Med. 1997;127:1045-1048. 


\section{Editorial}

3. Editorial Board. How to do right by the disabled. The New York Times. November 24, 2013:A22. Available at: http://www.nytimes.com/2013/11/ 25/opinion/how-to-do-right-by-thedisabled.html. Accessed June 17, 2014.

4. Haque OS, Waytz A. Dehumanization in medicine: Causes, solutions, and functions. Perspect Psychol Sci. 2012; 7:176-186.

5. Hendley M. Arizona legislators pass bill to remove words "Disabled" and "Handicapped" from state law. Available at: http://blogs.phoenixnewtimes. com/valleyfever/2014/04/arizona_legislators_pass_bill_disabled_handicapped_ disabilities.php. Accessed June 27, 2014.
6. Springboard Consulting. Strategic brand assessment. Available at: http://consult springboard.com/what-we-do/consulting/ marketplace-offerings/strategic-brandassessment/. Accessed on June 17, 2014.

7. Springboard Consulting. The ripple effect. Available at: http://consultspringboard.com/2009/articlesblogs-aboutdive-in/. Accessed on June 17, 2014. 